\title{
Ambivalências da fundação
}

\author{
MÁRIO MIRANDA FILHO \\ " $O$, it is excellent to have a giant's strength; \\ but it is tyrannous to use it like a giant" \\ William Shakespeare
}

RESUMO: O texto resenha O tirano e a cidade, de Newton Bignotto (São Paulo, Discurso Editorial, 1998).

UNITERIMOS:

democracia, tirania, filosofia política.

ons livros começam com bons títulos: é o caso desta obra de Bignotto. Cidade aqui remete ao grego Pólis e Pólis vista teoricamente como o lugar da vida civilizada, isto é, nem a vida tribal tacanha, nem o império descomunal e bárbaro. Não exatamente o lugar físico da habitação, mas esse nicho cravado no cosmo onde o homem, a partir do Mediterrâneo, definiu o modus vivendi ocidental. O título associa-a a obras como The city and man de Leo Strauss e La cité de l'homme de P. Manent. E por fim indica que a perspectiva do autor não é historicista - ainda somos tributários desta invenção grega - e portanto muito menos filiada à praga desconstrucionista que devasta sem reflorestar. E como não se propõe a fazer a história da tirania na Grécia, mas uma reflexão sobre as relações do tirano com a invenção da Pólis, é obra que se inscreve naquele domínio que Aristóteles batizou de Filosofia Política (A Política, L. III, 1282 b). Esta é talvez a melhor das surpresas desta obra, reatar com a tradição da disciplina Aristotélica que pensávamos estar definitivamente enterrada sob os quatro séculos de críticas dos modernos. $\mathrm{O}$ autor pede-nos que o acompanhemos a um mundo pré-moderno! Não é pedir demais? Se fôssemos ouvir os filósofos modernos parece que sim. Por exemplo, Maquiavel: “... como é meu intento escrever coisa útil... pareceu-me mais conveniente procurar a verdade pelo

Professor do Departamento de Filosofia da FFLCH - USP 
efeito das coisas do que pelo que delas se possa imaginar". Ou T. Hobbes, sempre contrário aos "antigos filósofos morais"; ou F. Bacon: "somos muito gratos a Maquiavel e outros que nos ensinaram a estudar o homem como ele é e não como deve ser"; ou Espinosa: "os filósofos... concebem os homens efetivamente, não tais como são, mas como eles próprios gostariam que fossem... devendo a política, tal como a concebem, ser tomada por quimera, ou como respeitando o domínio da utopia..."; ou Marx que caracterizava as reflexões de seus antecessores como "Politischer.. Nonsens"; ou Nietzsche para quem a "influência de Sócrates até hoje, e inclusive por todo o porvir afora, se alargou sobre a posteridade, qual uma sombra"; ou Heidegger solidário a Nietzsche ao condenar toda a filosofia pós-platônica como "esquecimento do ser”. Mais próximo de nós, há alguns anos G. Lebrun pedia, em artigo no Jornal da Tarde, "Para acabar com a cidade Grega" e, por fim, o atual Magnífico Reitor da USP assumindo o destempero de um colega seu proclama: "Chega... de Aristóteles!” (cf. Lebrun, 1984; Marcovitch, 1999)1 . Convenhamos, parece complot... Mas vamos ao livro.

$\mathrm{O}$ autor nos leva de início às paisagens aurorais do mundo grego, até o nascimento da Pólis, ou melhor, dessa que foi talvez a maior invenção do gênio grego: a política. Bignotto não nos leva a um périplo pelas origens da democracia: vai tomar o outro lado desta via, menos ensolarado, pois, como sabemos, a Grécia viu nascer simultaneamente à democracia, a tirania.

Historiadores como Vernant e Vidal Naquet demonstraram o quanto o nascimento da democracia representou de ruptura em relação à tradição, pondo em relevo, notadamente, o conceito de laicização. Reconduzindo-nos a este momento inaugural, o autor põe em foco esse regime gêmeo, a tirania, que nasce como resultado do trauma provocado pela ruptura com a autoridade do Basileus e da aristocracia do mundo Homérico. Momento raro e grave, em que os fios com o passado seccionam-se e em que as novas possibilidades de vida se oferecem de chofre a uma inteligência ainda tateante e como que embriagada com sua fresca liberdade. Momento demiúrgico, em que é preciso transformar aspirações difusas em leis, instituindo assim "novos modos e ordens", hora de crise e de personagens excepcionais: demiurgos, poetas, profetas, legisladores e... tiranos. Momento desejado e temido da Fundação, para o melhor e para o pior, conforme veremos em Platão.

Na Grécia, mostra-nos Bignotto, o primeiro a viver este drama foi Sólon que "reconhecendo o absurdo da condição anterior... expõe o corpo social a si mesmo" (p. 31). Dele diz bem Aristóteles "que preferiu a honra e a salvação do Estado à própria grandeza, ele que poderia submeter a todos à sua autoridade e se transformar no tirano de Atenas" (p. 27). Verdadeirofounding father, Sólon "soube detectar o perigo contido num poder que se distancia ao extremo da

${ }^{1}$ G. Lebrun é também a fonte da fonte "lúcida" do Magnífico Reitor (cf. Lebrun, 1988, p. 76). cidade, à medida que identifica a lei com a vontade do governante" (p. 35).

Um século depois de Sólon, século marcado pelas primeiras tiranias (561 a.C.), Heródoto já enuncia com todas as letras o conceito de tirania como Sólon o esboçara: "Um tirano... tem inveja da maneira de conduzir-se e 
viver dos homens de bem, e se compraz com os piores de todos os cidadãos... é o mais inconsequiente de todos os homens... fica transtornado por não ser adulado servilmente... Mas ainda vou dizer o maior de seus defeitos: ele subverte os costumes ancestrais, violenta as mulheres e condena as pessoas à morte sem mandar julgá-las" (p. 38). Com Sólon e Heródoto já dispomos de um saber preliminar sobre este momento de crise em que o homem, rompendo com o ancestral, pode se transformar num deus ou numa besta; nas palavras de Bignotto "estamos diante de uma página importante da história... em que se acha terminada a invenção do tirano" (p. 39).

É admirável como, nos três capítulos seguintes - "O tirano trágico", "O tirano clássico" e "A educação do tirano" - o autor nos expõe a variedade e a consistência da reflexão grega sobre a liberdade e a tirania como uma dualidade inscrita na Fundação. Seu capítulo sobre a tragédia - cuja originalidade é preciso sublinhar - deixa-nos a impressão de que poucas vezes um gênero artístico terá sido tão significativo para o povo que o viu nascer. "As tragédias foram o meio privilegiado de que se serviram os Atenienses para dar plena expressão às dúvidas e conflitos que os atemorizavam e estimulavam na busca de uma nova compreensão dos limites da extraordinária experiência política que viviam" (p. 55). Suas análises de Hemon e de Creonte, destacando este último como personagem ameaçador, não apenas à religiosidade, mas sobretudo porque "revela aos cidadãos os limites de sua condição de inventores da lei” (p. 72), são contribuições para ficar. Não menos notável é a análise do Édipo-Tirano, peça onde os cidadãos podiam ver em Édipo as ambiguidades da própria política ateniense: "Muito alto em direção ao zênite, este homem lançou sua flecha, ele era mestre de uma felicidade sem sombras" (cit. à p. 81), Édipo que por querer ultrapassar a condição humana mais se aproxima do bestial. "O que a tragédia faz, e que amedronta a orgulhosa Atenas, diz o autor, é mostrar que a experiência da tirania, representada como a explosão dos limites do humano..., é parte constituinte da cidade, está inscrita em suas possibilidades" (p. 83). O exame da tragédia permite ao autor formular a primeira versão de sua tese: "A tirania de Édipo é pois o oposto simétrico [da] democracia... Ela fornece a imagem de um ideal negativo...” (p. 83). A simplicidade lapidar dos versos de Sófocles resume a lição trágica: "Uma cidade feita por um só não existe" (cit. à p. 67).

Mas é em Platão que encontraremos as reflexões definitivas sobre a questão da Fundação e da tirania, reflexões complementadas solidariamente por Aristóteles. Como Bignotto sabe corresponder a estas reflexões seu terceiro capítulo é o ponto alto do livro. Aqui, nada de concessões, nem aos sofistas, cuja teoria não "permite uma verdadeira formulação do problema do mal” (p. 95), nem às oposições apressadas do tipo Platão-idealista/Aristótelesempirista, "perfeito absurdo" (p. 149). Como não é possível, aqui, sequer dar uma idéia da riqueza de suas análises d'A República, O Político e As Leis, de Platão, e d'A Política de Aristóteles, vou me limitar a destacar a articulação dos dois temas referentes à Fundação, a tirania e o legislador, porventura os 
de maior relevo na obra em apreço.

Inventores da política, os gregos se viram no IV século a.C. às voltas com a questão inadiável de sua fundamentação teórica. Esta questão os filósofos a trataram - e aqui nosso autor segue L. Strauss (p. 155) - ancorando-a no tema superior do melhor regime, para cuja obtenção o que "importa é o processo de formação dos homens (paidéia)" (p. 156). Bignotto apreende aqui, talvez, a diferença essencial que distingue a filosofia política clássica da moderna (com a possível exceção de Rousseau). Ao contrário dos antigos, que jamais desvincularam a Paidéia - termo que Cícero e Varrão traduzem por Humanitas, e cuja forma mais alta é a razão filosófica - de seus projetos políticos, os modernos pensaram chegar aos mesmos resultados tomando o homem como ele é, sem exigências, (entenda-se, como ser passional) confiando apenas em que as instituições corretas emancipariam as paixões conduzindo-as à paz e ao ideal da commodious living com o auxílio da ciência. Este dilema - que os modernos pensaram através da oposição realismo/utopia foi vivido na Grécia pela oposição entre convenção (sofistas) e natureza (Platão e Aristóteles). Se a política - a justiça, o direito - nada mais era do que a reunião dos meios convencionais para se obter vantagens sobre os outros, então transformava-se numa arte das aparências: "parecer justo sem sê-lo"; ou pior, numa mera prova de forças. Mas a filosofia clássica negava que ela fosse uma mera arte (artificial). Ao contrário, sendo o homem um animal político, a política está inscrita na natureza: é pois algo substantivo, o direito é literalmente natural. Não obstante, Estados não nascem prontos: é preciso a intervenção humana para Formá-los: daí o tema clássico do legislador, o fundador de Estados. É o que vemos Platão fazendo de modo voluntariamente abusivo n'A República e mais moderada ou "realisticamente" em As Leis, e Aristóteles em A Política (1. VII e VIII). Em suma, a tarefa que Sólon viveu parcialmente, Platão e Aristóteles viveram e pensaram plenamente, sem abandonar a humanitas, isto é, sem, por exemplo, (des)caracterizar o homem como lupino.

Fundar países? nós que assistimos à fundação de Brasília - “apenas" uma capital - podemos imaginar a dimensão da tarefa. Bignotto chama a atenção para o caráter singular deste momento: "Os atenienses recorreram com frequiência à idéia de que seu passado estava ligado à história dos deuses, e não à dos outros homens..." vinculando "a cidade diretamente a uma deusa" (p. 104). Trata-se, talvez, do momento mais dramático porque o de maior transparência na vida de um povo. Como assinala Montaigne: "as leis se mantêm em crédito, não porque são justas, mas porque são leis. É o fundamento místico de sua autoridade; não têm outro..." (Villey, 1961, p. 1072)². Ou alguns séculos depois o federalista A. Hamilton, num momento capital da história moderna: "Estava reservado à América resolver esta importante questão; se os homens são capazes de se dar um bom governo por própria refle-

${ }^{2}$ Meu agradecimento ao amigo Sérgio Cardoso pela localização deste importante texto. xão e escolha, ou se a Providência os condenou a receberem eternamente a sua constituição política, da força ou do acaso... verdadeira desgraça seria, para todo o gênero humano, se a escolha que fizéssemos não fosse boa”. $\mathrm{O}$ 
final sombrio ecoa preocupações que já tinham sido as de Platão. "A arte da fundação, diz Bignotto, revela a grandeza da filosofia e seus riscos” (p. 106). É hora do filósofo tomar o lugar do poeta ou do profeta (lembremos que no mundo judaico-cristão-islâmico a fundação esteve desde o início assegurada pela Revelação). Mas “se a filosofia deve abandonar o mito, nem por isso pode desconhecer os problemas que resolve" (p. 108) e entre estes está o da possibilidade do fracasso. Com isto voltamos em cheio ao tema de Bignotto, pois como não se cansaram de advertir os gregos'lá onde... fracassam os grandes fundadores... nascem os tiranos" (p. 109). A tarefa da filosofia será a de delimitar o domínio próprio da política por oposição ao reino da violência. Não que política e violência sejam termos mutuamente excludentes - Platão não é tão sonhador... Mas então, como nota o autor em um momento capital de sua tese, o fundador se aproxima perigosamente do tirano. Com efeito, pergunta: "Como distinguir a violência exercida em nome da verdade daquela exercida em nome de pequenos interesses, mas que faz apelo precisamente à verdade e ao absoluto?" (p. 113) De fato, diz o autor, para os clássicos, a tirania não é um regime. É, isto sim, “o negativo perfeito do regime ideal... [ e portanto, um] parâmetro negativo regulador da vida na cidade na medida em que aponta para a última fronteira do humano antes do reino da pura violência, assim como o regime ideal aponta para as fronteiras da vida humana nos limites superiores do divino" (p. 114). Ao enunciar esta tese em toda sua plenitude, Bignotto põe fim à persistente tentativa que se tem feito, a partir de Nietzsche e do liberalismo, de associar Platão ao totalitarismo. Com essa precisa análise da psicologia platônica, ele nos mostra que os clássicos não desconheciam os componentes teratológicos da alma humana, sempre pronta a instaurar a barbárie.

Nosso século assistiu as hecatombes soviética e nazista e é testemunha diária de tentativas de "destruição do espaço público". Longe, pois, de descartar uma reflexão filosófica (da qual a obra a que ora nos referimos é exemplo) que demonstre a possibilidade sempre presente dessa destruição, o que se impõe é, ao contrário, o reforço dos elos que ligam a reflexão política atual a suas origens clássicas. Como diz Leo Strauss, somente quando temos em mente o indissolúvel elo entre sabedoria e moderação é que nos protegemos contra estes dois perigos gêmeos: de um lado, a busca da política como meio para a realização de esperanças visionárias; de outro, a tentação de desprezá-la, justamente porque ela não se presta à realização de tais esperanças.

Recebido para publicação em novembro/1999 
MIRANDA FILHO, Mário. Ambivalence of foundation. Tempo Social; Rev. Sociol. USP, S. Paulo, 12(1): 219-224, May 2000.

UNITERIMS:

democracy,

tyranny,

political philosophy.
ABSTRACT: This text is a review of $O$ tirano e a cidade by Newton Bignotto (São Paulo, Discurso Editorial, 1998).

\section{REFERÊNCIASBIBLIOGRÁFICAS}

Lebrun, G. (1984) Para acabar com a cidade grega. Jornal da Tarde, São Paulo, 26/05, p. 7.

. (1988) O avesso da dialética. São Paulo, Companhia das Letras.

Marcovitch, J. (1999) Universidade e desemprego. O Estado de S. Paulo, São Paulo, 08/06, p. A2.

VILLEY, Pierre. (1961) Les essais de Montaigne. Paris, PUF. 